\title{
PEMEROLEHAN BAHASA INDONESIA ANAK USIA 3-5 TAHUN DI PAUD LESTARI DESA BLIMBING KECAMATAN PACIRAN KABUPATEN LAMONGAN
}

\author{
Desy Indah Wulandari \\ Universitas Negeri Surabaya \\ desywulandari16070835059@mhs.unesa.ac.id
}

\section{ABSTRAK}

\section{ABSTRACT}

Perkembangan bahasa anak dimulai sejak lahir sampai usia 5 tahun secara khusus telah memperoleh beribu-ribu kosakata, sistem fonologi dan gramatika serta aturan kompleks yang sama untuk menggunakan bahasa mereka dengan sewajarnya dalam banyak latar sosial. Berdasarkan pernyataan tersebut penelitian ini bertujuan untuk menganalisis pemerolehan bahasa Indonesia anakanak usia dini yang berumur 3 hingga 5 tahun di PAUD Lestari desa Blimbing, kecamatan Paciran, Lamongan di lingkungan Sekolah pada tataran fonologi, morfologi, sintaksis dan semantik. Pusat dari penelitian ini adalah pemerolehan bahasa Indonesia pada anak-anak usia dini di Desa Blimbing Kecamatan Paciran Kabupaten Lamongan pada tataran fonologi, morfologi dan sintaksis serta semantik di lingkungan sekolah. Metode penelitian yang digunakan adalah metode deskriptif kualitatif dengan model analisis deskriptif. Hasil penelitian menunjukkan bahwa: (1) Anak usia 3 tahun mengalami perubahan bunyi /r/ diucapkan /l/, /s/ diucapkan /c/ dan bunyi sedangkan pada anak yang berusia 4 - 5 tahun sudah memperoleh semua bunyi vocal dan bunyi konsonan, tidak ada perubahan bunyi /r/ yang berubah /l/. (2) Anak usia tiga tahun dalam pemerolehan morfologi belum memperoleh kata yang mendapatkan proses afiksasi serta muncul morfem yang tidak utuh sedangkan pada anak yang berusia 4 tahun sudah muncul morfem yang utuh dan prefiks $\{$ meN- $\}$ dan usia 5 tahun lebih banyak muncul pemerolehan afiksasi. (3) Pada tataran sintaksis, anak yang berusia 3 tahun hanya memperoleh ujaran dua kata, sedangkan anak yang berumur 4-5 tahun sudah memperoleh ujaran beberapa kata (4) Pada tataran semantik hampir semua ujaran anak mengandung makna denotatif, ada pula kalimat yang muncul dengan makna konotatif.

\section{Kata Kunci: Pemerolehan Bahasa, Anak Usia Dini}

The development of the child language is begin from born to the age of 5 years has in particular gained thousands of vocabulary, phonological and grammatical systems and the same complex rules for using their language appropriately in many social background. Based on that statement, this study aims to analyze the acquisition of Indonesian children early age 3 to 5 years old in PAUD Lestari Blimbing village, Paciran subdistrict, Lamongan in school environment at the level of phonology, morphology, syntax and 
semantics. From this background, the center of this research is the acquisition of Indonesian language in children of early age in Blimbing Village, Paciran Subdistrict, Lamongan Regency, at the level of phonology, morphology and syntax and semantics in the school environment. The research method that is used is qualitative descriptive with descriptive categorical analysis model. The results showed that: (1) 3 years old experiencing sound /r/ pronounced /l/, /s/ is pronounced /c/ while in children aged 4-5 years have obtained all vocal sounds and consonant sounds, no change of sound $/ \mathrm{r} /$ changed /l/. (2) Three years old children in morphological acquisition have not obtained a word that gets the affixation process and appears morpheme is not intact while in children aged 4 years have appeared the whole morphemes and prefix $\{\mathrm{meN}-\}$ and the age of 5 years more emerging acquisition of affixation. (3) On a syntactic level, a 3 years old child receives only two words of speech, while a 4-5 year old child has received a few words of speech. (4) At the semantic level almost all children speeches contain denotative meanings, there is also a sentence that appears with connotative meaning.

\section{Keywords: Language acquisition, Children in Early Age}

PENDAHULUAN Bahasa merupakan alat komunikasi yang diperoleh manusia sejak lahir. Pada awal bayi dilahirkan belum memiliki kemampuan dalam berbicara dengan orang lain. Bahasa ibu adalah satu sistem linguistik yang pertama kali dipelajari secara alamiah dari ibu atau keluarga yang memelihara seorang anak (Chaer dan Agustina, 2004:81). Sebagian besar anak Indonesia memiliki bahasa pertamanya adalah bahasa daerahnya masing-masing. (Chaer dan Agustina, 2004:226). Perkembangan bahasa anak dimulai sejak lahir sampai usia 5 tahun secara khusus telah memperoleh beriburibu kosakata, sistem fonologi dan gramatika serta aturan kompleks yang sama untuk menggunakan bahasa mereka dengan sewajarnya dalam banyak latar sosial.

Pemerolehan bahasa atau akuisisi bahasa adalah proses yang berlangsung di dalam otak seseorang kanak-kanak ketika dia memeroleh bahasa pertamanya atau bahasa ibunya. Pemerolehan bahasa biasanya dibedakan dari pembelajaran bahasa (language learning). Pembelajaran bahasa berkaitan dengan proses-proses yang terjadi pada waktu seseorang kanak-kanak memperlajari bahasa kedua, setelah dia memperoleh bahasa pertamanya. Jadi, pemerolehan bahasa berkenaan dengan bahasa pertama sedangkan pembelajaran bahasa berkenaan dengan bahasa kedua. Namun, banyak juga yang menggunakan istilah pemerolehan bahasa untuk bahasa kedua (Chaer, 2015:167).

Pemerolehan bahasa disebabkan oleh unsur biologi dan neurologi yang disebut bahasa ibu, sedangkan pembelajaran bahasa cenderung mengikuti langkah-langkah yang diterapkan dalam kajian bahasa pertama atau bahasa ibu. Menurut Arifuddin (2013:116) pemerolehan (acquisition) bahasa mengacu kepada 
pajanan langsung (exposure) dalam situasi bahasa, proses berlangsung dalam otak anak ketika dia memeroleh bahasa ibu atau bahasa pertamanya. Sementara itu, pembelajaran (learning) mengacu pada aktivitas belajar secara sadar dan terprogram dalam situasi kelas formal dengan bantuan pengajar (guru).

Bahasa pada umumnya masih menggunakan struktur bahasa yang masih kacau dan masih mengalami tahap transisi dalam berbicara, sehingga sukar untuk dipahami oleh mitra tuturnya. Selain menggunakan struktur bahasa yang masih kacau, anak-anak juga cenderung masih memiliki keterbatasan dalam kosakata dan dalam pelafalan fonemnya secara tepat. Lingkungan sangat mempengaruhi perkembangan bahasa anak. Seorang mitra tutur pada anak harus menguasai kondisi atau lingkungan sekitarnya untuk dapat memahami maksud dari pembicaraan anak.

Ada dua proses yang terjadi ketika seseorang kanak-kanak sedang memperoleh bahasa pertamanya, yaitu proses kompetensi dan proses performansi. Kompetensi adalah proses penguasaan tata bahasa yang berlangsung secara tidak disadari. Proses ini menjadi syarat untuk terjadinya proses performansi yang terdiri dari dua buah proses, yakni proses pemahaman dan proses penerbitan atau proses menghasilkan kalimat-kalimat. Terdapat tiga teori atau hipotesis, yaitu hipotesis nurani, hipotesis tabularasa, hiotesis kesemestaan kognitif. Terdapat juga berbagai jenis-jenis dalam pemerolehan bahasa yakni fonologi, sintaksis, dan semantik. Di samping itu, ada bahasan pula mengenai pemerolehan pragmatik.

Proses pemerolehan bahasa seorang anak berkaitan erat dengan konsep universal yang memengaruhi pemerolehan bahasa bergantung pada sifat kodrati komponen bahasa. Komponen fonologi berkaitan dengan neurobiolgi manusia, sedangkan sintaksis dan semantik memiliki kadar universal yang lebih rendah. Pada sintaksis dan semantik urutan pemunculan bunyi tidak langsung terkait dengan pertumbuhan biologi dan neurologi anak. Pada komponen sintaksis ada pola-pola kalimat yang diperoleh secara universal. Anak selalu memulai dengan ujaran yang berupa satu kata, kemudian berkembang menjadi dua kata, setelah itu tiga kata atau lebih. Komponen semantik lebih labil lagi karena kata yang dikuasai dan jumlahnya sangat bergantung pada keadaan masing-masing anak. Pola urutan universal yang umumnya diikuti anak adalah kosa kata yang dikuasai anak dari objek yang ada disekelilingnya dan yang ada saat itu ada. Anak belum bisa membayangkan benda yang tidak ada, atau peristiwa yang sudah atau belum terjadi.

Jaman sekarang banyak sekali orang tua murid yang membawa buah hati mereka untuk memasuki dunia "belajar sambil bermain" atau istilah lainnya memasuki masa Pendidikan Anak Usia Dini (PAUD). Dari perkembangan otak manusia, maka tahap perkembangan otak pada anak usia dini menempati posisi yang paling vital yakni mencapai $80 \%$ perkembangan otak. Banyak orang tua yang percaya bahwa semakin dini anak mereka memperoleh suatu pendidikan maka semakin cepat berkembangnya 
kosakata-kosakata yang akan mereka peroleh serta akan mempunyai pengalaman. Hal ini dinamakan fase golden age (usia emas), fase yang paling penting dalam menunjang pemerolehan bahasa seorang anak. Fase dimana otak seorang anak sedang tumbuh dan berkembang serta lebih banyak menangkap serta menyerap informasi secara maksimal.

Berdasarkan pernyataan tersebut penelitian ini bertujuan untuk menganalisis pemerolehan bahasa Indonesia anak-anak usia dini yang berumur 3 hingga 5 tahun di PAUD Lestari desa Blimbing, kecamatan Paciran, Lamongan di lingkungan Sekolah pada tataran fonologi, morfologi, sintaksis dan semantik. Dari latar belakang tersebut, pusat dari penelitian ini adalah pemerolehan bahasa Indonesia pada anak-anak usia dini di Desa Blimbing Kecamatan Paciran Kabupaten Lamongan pada tataran fonologi, morfologi dan sintaksis serta semantik di lingkungan sekolah.

METODE

\section{PEMBAHASAN}

Penelitian ini menggunakan rancangan deskriptif kualitatif. Penelitian dilaksanakan dengan tujuan untuk mendeskripsikan pemerolehan bahasa di bidang fonologi, morfologi, sintaksis, dan semantik anak-anak usia dini. Sumber data dari penelitian ini adalah anak- anak usia dini yang mengikuti PAUD di Desa Blimbing, Kecamatan Paciran, Kabupaten Lamongan. Setiap anak yang berusia 3 sampai 5 tahun setiap kelompok diambil 2 anak sebagai subjek penelitian sehingga total sampel berjumlah 6 subjek penelitian. Data ini bersifat deskriptif yang berarti bahwa pemerolehan fonologi, morfologi, sintaksis dan semantik pada anak usia dini. Penelitian ini merupakan penelitian kualitatif karena untuk mendeskripsikan secara sistematis, faktual serta akurat mengenai pemerolehan bahasa tersebut. Penelitian ini menggunakan metode observasi atau pengamatan langsung atas obyek penelitian. Melalui metode observasi peneliti dapat melihat secara langsung kegiatan yang dilakukan anak dalam berkomunikasi dengan orang-orang yang berada di sekitarnya. Metode penelitian ini dilakukan dengan teknik rekam dan catat. Peneliti menggunakan alat perekam mobile phone. Hasil rekaman akan dipindahkan ke dalam laptop dan kemudian ditranskipkan ke dalam bentuk tulisan untuk dianalisis.

\section{Pemerolehan Bahasa Indonesia dalam tataran fonologis}

Dalam analisis fonologis, peneliti mentranskripsikan data ke dalam bentuk fonetis dan teks. Hal ini dilakukan untuk memaparkan ujaran yang diungkapkan oleh anak. Selanjutnya data akan dituliskan untuk memperlihatkan ujaran yang diucapkan oleh subjek penelitian ini yaitu anak yang berumur 3 sampai 5 tahun.

(1) [anter ibu] [aek cepeda] [maam mi] [bica] [baloncu] [da] [ima] [upa-upa] [alnanya] [ijo uning elabu] [melah uda dan bilu] [dah] [ugak bica] [letus alon ijo] [dol] 
Diantar ibu. Naik sepeda. Makan mie. Bisa balonku ada lima. Rupa-rupa. Warnanya. Hijau kuning kelabu. Merah muda dan biru. Udah. Tidak bisa.

Pada data (1) diatas terdapat bunyi bunyi bahasa yang mengalami perubahan pada fonem. Ada satuan fonem yang lesap seperti pada [lele] yang seharusnya Rere, /r/ berubah menjadi /l/ dan [alnaya], [melah], [bilu] dan [dol] yang seharusnya [warnanya], [merah], [biru], dan [dor]. Hal tersebut terjadi sangat wajar dan biasa dilakukan oleh anak. Usia anak juga belum memadai untuk kecakapan berbicara. Rere adalah anak yang dikatakan masih pelat, dengan demikian banyak fonem /r/ yang berubah menjadi /l/. Rere tidak akan selamanya menjadi pelat, seiring bertambahnya usia maka Rere akan mengurangi pelat tersebut dengan fonem yang tepat. Tidak hanya fonem / $\mathrm{r}$ / yang berubah menjadi fonem /l/ ada pula fonem /s/ yang berubah menjadi fonem /c/. seperti pada kata [bica] yang seharusnya [bisa]. Hal ini sejalan dengan pendapat Jacobson (dalam Chaer, 2009:204-205) urutan pemerolehan kontras fonemik bersifat universal. Artinya, bisa terjadi dalam bahasa apapun dan oleh kanak-kanak manapun. Maka setelah konsonan bilabial dan vokal lebar di atas, akan muncul oposisi bunyi oral dan bunyi nasal seperti [pa-pa] [ma-ma]. Kemudian diikuti oleh oposisi labial dan dental/alveolar, seperti [pa-pa], [ta-ta], atau [ma-ma], [na-na]. Jadi, urutan pemerolehan konsonan adalah bilabial-dental (alveolar) - palatal - velar. Ini berarti, apabila seorang kanak-kanak telah dapat membunyikan konsonan friaktif, berarti dia juga telah mampu membunyikan bunyi-bunyi hambat. Munculnya konsonan belakang dalam ucapan kanak-kanak menandakan bahwa dia juga telah menguasai konsonan depan. Kontras vokal pertama yang diperoleh kanak-kanak adalah kontras vokal lebar [a] dengan vokal [i]. Kemudian diikuti oleh kontras vokal sempit depan [i] dengan vokal sempit belakang [u]. Sesudah itu antara vokal [e] dan vokal [u]; vokal [o] dengan vokal [e]. Rere akan mengubah pemerolehan bahasa tersebut yang bermula dari menirukan orang tua dengan latihan dan dukungan keluarga beserta pengajar (guru) agar dapat berbahasa yang baik dan sesuai. Dengan demikian faktor keluarga akan berperan penting dalam kesuksesan seorang anak.

(2) $[$ ila $][\mathrm{Ibu}]$ [motol] [elom] [beli nanti] [bisak] [balonku] [ada] [ima] [rupa-rupa] [warnanya] [hijo kuning kelabu] [merah uda dan biru] [meletus alon hijo] [dor] [atiku amat] [kacau] [balonku inggal pat] [gang erat-erat]

Gilang. sama ibu. Motor. belom. Beli nanti. bisa. Balonku. Ada, lima. Rupa-rupa. Warnanya. Hijau kuning kelabu. Merah muda dan biru. Meletus balon hijau. Dor. Hatiku. Sangat kacau. Balonku tinggal empat. Pegang erat-erat. 
Data (2) di atas merupakan tuturan anak yang berumur 4 tahun yaitu Gilang dalam memeroleh bunyi pengucapan pun sudah mulai jelas. Namun, ada beberapa kata yang belum sesuai dengan kaidah yang benar, contoh [hijo] yang seharusnya [hijau] ada pengurangan fonem disana. Ada pula fonem yang tidak diucapkan yaitu [atiku] yang seharusnya [hatiku]. Dibanding Rere, gilang tidak termasuk anak yang pelat dan terbiasa merubah fonem /r/ menjadi /l/ seiring bertambahnya usia maka perubahan tersebut semakin berkurang, namun masih beberapa kata yang hilang fonemnya. Pemerolehan bunyi berjalan selaras dengan kodrat bunyi itu sendiri. Bunyi pertama yang keluar waktu anak mulai berbicara adalah kontras antara konsonan dan vokal. Dalam hal vokal, hanya bunyi /a/, /i/, dan /u/ yang akan keluar terlebih dahulu. Dari tiga bunyi ini /a/ akan keluar duluan daripada /i/, atau /u/. hal ini disebabkan ketiga bunyi tersebut membentuk apa yang dinamakan "Sistem Vokal Minimal” (Minimal Vocalic System). Seperti pada data (2) diatas banyak vokal /a/ yang mudah diucapkan anak, terbukti dari kata [pat] yang seharusnya [empat] dimana vokal /e/ tidak diucapkan.

(3) [vivi]. [tadi diantar] [ma mama] [ke sini] [dah dah kok]. [vivi bisa sendiri kok] [balonkuh] [ada] [lima] [rupah-rupah] [warnanya] [hijo kuning kelabuh] [merah mudah dan biruh] [meletus balon hijo] [dor] [hatikuh sangat] [kacau] [balonkuh tinggal empat] [kupegang erat-erat]

Vivi. tadi diantar mama. Ke sini. Sudah sudah kok. Vivi bisa sendiri kok. Balonku. Ada, lima. Rupa-rupa. Warnanya. Hijau kuning kelabu. Merah muda dan biru. Meletus balon hijau. Dor. Hatiku. Sangat kacau. Balonku tinggal empat. Ku pegang erat-erat.

Data (4) diatas menunjukkan bahwa Vivi anak yang berumur 5 tahun sudah hampir memeroleh bunyi -bunyi bahasa yang benar. Tidak ada perubahan bunyi fonem, Terjadi reduplikasi fonologi karena si anak merasa malu sehingga terjadi seperti [dah dah]. Ada pula penambahan fonem /h/ disetiap kata yang berakhiran /a/ dan /u/, seperti [balonkuh], [rupah-rupah], [kelabuh] [merah mudah dan biruh] [hatikuh].

Dari hasil penelitian pemerolehan fonologi dapat dilihat bahwa anak-anak yang berusia 3-5 tahun menyederhanakan bunyi-bunyi bahasa yang kompleks. Ada beberapa bunyi konsonan seperti /r/ yang berubah bunyi menjadi /l/ dan /s/ yang menjadi /c/ hal ini sering muncul pada anak yang berumur 3- 5 tahun, namun seiring bertambahnya usia, akan berangsur menghilang. Hal ini juga dikarenakan kebiasaan yang dilakukan orang tua dan orang-orang disekitarnya yang sering mengucapkan hal yang sama. Ada sejumlah proses dasar yang digunakan anak-anak ketika berbicara. Hal tersebut adalah tahapan yang dilalui oleh anak-anak untuk dapat berbicara seperti orang dewasa. Seiring dengan bertambahnya usia anak dan diperolehnya keterampilan-keterampilan bahasa yang 
lebih kompleks, anak akan mulai meninggalkan pengucapanpengucapan yang sederhana.

\section{Pemerolehan Bahasa Indonesia dalam Tataran Morfologi}

Dari transkip data (1) sampai (3) diperoleh data yaitu ujaran pada anak-anak yang berumur 3 tahun pada data 1 belum muncul morfem yang memeroleh afiksasi, bahkan banyak morfem yang sebagian seperti /dah/ /yum//ma/ yang seharusnya /sudah/, /belum/, /bersama/, Namun pada anak yang berumur 4-5 tahun pada data (2) dan (3) sudah muncul morfem yang mendapatkan proses afiksasi mendapat prefiks maupun sufiks, namun infiks maupun konfiks belum muncul. pada anak yang berumur 4-5 tahun terdapat morfem yang mengalami reduplikasi.

Pada anak yang berusia tiga tahun belum menunjukkan pemerolehan afiksasi. Pada usia tiga tahun, pemerolehan morfologi kebanyakan kata-kata yang monomorfemik. Bentuk pasif di- juga mulai muncul pada umur tiga tahun. pada usia empat tahun prefiks formal $\{$ ber- $\}$ dan $\{$ meN- $\}$ sudah mulai muncul walaupun masih jarang muncul. Pada usia lima tahun anak sudah mencapai perkembangan verba, netralisasi sufiks $\{-k a n\}$ dan $\{-i\}$ yang menjadi $\{$ in $\}$ pada /dibeliin/ yang seharusnya /dibelikan/.

\section{Pemerolehan Bahasa Indonesia dalam Tataran Sintaksis}

Pemerolehan bahasa Indonesia dalam tataran sintaksisis ini peneliti menemukan beberapa kesalahan berbahasa, meliputi: kesalahan frasa, kesalahan klausa, dan kesalahan kalimat.

\section{(4) [maem udah kok] [anter ibu]}

Dari data (4) tuturan yang diucapkan oleh Rere usia 3 tahun, terdapat kesalahan frasa yaitu pada kata "maem udah" yang seharusnya "sudah makan”. Kesalahn tersebut tergolong frasa kerja yang salah karena strukturnya yang tidak tepat karena kata keterangan atau modalitas terdapat sesudah kata kerja. Begitu juga kesalahan pada "anter ibu" yang berartikan "diantar ibu" seharusnya "diantar oleh ibu”. Pernyataan "anter ibu” Rere telah menghilangkan kata oleh dalam frasa kerja pasif. Frasa yang berstruktur dimulai dari kata kerja pasif bertemu kata benda seharusnya tidak menghilangkan kata oleh atau perlu ada kata oleh diantaranya untuk memperjelas makna pasif frase tersebut. Hal ini merupakan suatu bukti bahwa adanya kompetensi anak dalam pemerolehan bahasa pertamanya telah diperoleh walaupun masih dalam bentuk sederhana.

(5) [pergi ke rumahnya mbah sama adek] [mainannya teman]

Pada data (5) di atas, merupakan tuturan anak yang berusia 4-5 tahun, anak tersebut mulai menghasilkan kalimat-kalimat tunggal seperti berpola SP, S-P-O, K-P-O dan K-S. Walaupun masih ada 
beberapa yang tidak gramatikal, Penyusunan kalimat yang diucapakan oleh anak usia 4-5 tahun masih terpengaruh pada struktur bahasa daerah, terbukti dari "pergi rumahnya mbah" yang seharusnya cukup dengan "pergi ke rumah mbah" dan "mainannya teman" yang harusnya "mainan teman". Berbahasa Indonesia dalam situasi resmi kadang-kadang tidak disadari menerapkan struktur bahasa daerah, hal tersebut disebabkan karena lingkungan anak yang tinggal di daerah. Selain faktor lingkungan, Faktor Latar Belakang Sosial juga mempengaruhi variasi pemerolehan bahasa. Faktor ini mencakup struktur keluarga, afiliasi kelompok sosial, dan lingkungan budaya. Semakin tinggi tingkat interaksi sosial sebuah keluarga, semakin besar peluang anak memperoleh bahasa. Sebaliknya semakin rendah tingkaf interaksi sosial sebuah keluarga, semakin kecil pula peluang anak memperoleh bahasa. Hal lain yang turut berpengaruh adalah status sosiai. Anak yang berasal dari golonganm status sosiai ekonomi rendah rnenunjukkan perkembangan yang lamban dalam pemerolehan bahasa. Namun seiring bertambahnya usia mereka akan mengembangkannya ke dalam bentuk yang lebih kompleks dan sesuai, hal ini dikarenakan variasi pemerolehan bahasa pada anak sangat beragam, beberapa ada yang cepat, ada pula yang lambat.

\section{Pemerolehan Bahasa Indonesia dalam Tataran Semantik}

Dari hasil penelitian, data (1) hingga data (3) didapatkan hasil bahwa anak yang berumur 3-5 tahun banyak menggunakan makna denotatif pada jawaban-jawaban yang dilontarkan sedangkan pada nyanyian bermakna konotatif, walaupun ada beberapa jawaban yang mengandung makna konotatif. Sedangkan pada anak yang berumur 5 tahun jawabannya bermakna denotatif hanya pada nyanyian bermakna konotatif. Makna denotatif adalah makna sewajarnya dari kata dan mempunyai makna umum (Udjang, 2010:42) denotatif mengandung kata secara objektif, apa adanya. Artinya, makna sebuah kata yang dirumuskan untuk pertama kalinya sebagai makna dasar.

Semakin bertambah usia anak-anak, pengenalan fitur semantik ini semakin sempurna. Garcia (dalam Yulianto, 2011:3) pemerolehan bahasa anak dalam dikatakan mempunyai ciri kesinambungan, memiliki suatu rangkaian kesatuan, yang bergerak dari ucapan satu kata sederhana menuju gabungan kata yang lebih rumit. Pada anak usia empat sampai lima tahun mulai mengetahui makna kata benda dan kata kerja walaupun masih terbolak balik dalam menempatkannya sebagai kalimat seperti "beli nanti” yang seharusnya "nanti beli" seperti data (2) yang diperoleh peneliti.

\section{(6) [make kaki] [sekolah sama mbah]}

Dari data (6) diatas, merupakan tuturan seorang anak seperti kata "make kaki" yang bermaksud menggunakan kaki untuk berjalan dan "sekolah sama mbah" yang berarti diantar neneknya ke sekolah. Makna denotatif dan makna konotatif merupakan gejala 
bahasa yang alamiah karena anak-anak walaupun orang dewasa menggunakan kedua makna ini dalam berkomunikasi. Anak-anak cenderung ingin menyatakan amanat yang ingin diutarakan secara langsung tanpa maksud lainnya. Semakin bertambah usia anakanak, pengenalan fitur semantik ini semakin sempurna. Tahap penyempitan makna kata berlangsung antara umur 1 hingga 1,6 tahun. Pada tahap ini anak-anak menganggap satu benda tertentu yang dicakup oleh satu makna menjadi nama dari benda itu. Contohnya meong hanyalah kucing yang dipelihara di rumah. Selanjutnya yaitu tahap medan makna semantik. Berlangsung pada anak yang berusia 2,6 hingg 5 tahun, seperti data (6) dalam penelitian. Pada tahap ini anak-anak mulai mengelompokkan katakata yang berkaitan ke dalam satu medan semantik. Pada masa perkembangan pralinguistik anak mengembangkan konsep dirinya. Anak akan berusaha membedakan dirinya dengan orang lain atau subjek yang lain. Dengan demikian ada hubungan dengan objek dan tindakan. Pada kata anak tahap pertama, anak akan berupaya mengumpulkan nama benda-benda dan orang yang ia jumpai.

\section{SIMPULAN}

Berdasarkan hal tersebut dapat disimpulkan, bahwa anak-anak usia dini khususnya PAUD Lestari di desa Blimbing Kecamatan Paciran Kabupaten Lamongan, sudah mampu memperoleh bahasa Indonesia dari segi fonologi, morfologi, sintaksis dan semantik. Hasil yang diperoleh (1) Anak usia 3 tahun mengalami perubahan bunyi /r/ diucapkan /l/ , /s/ diucapkan /c/ dan bunyi sedangkan pada anak yang berusia 4 - 5 tahun sudah memperoleh semua bunyi vocal dan bunyi konsonan, tidak ada perubahan bunyi /r/ yang berubah /l/. (2) Anak usia tiga tahun dalam pemerolehan morfologi belum memperoleh kata yang mendapatkan proses afiksasi serta muncul morfem yang tidak utuh sedangkan pada anak yang berusia 4 tahun sudah muncul morfem yang utuh dan prefiks $\{$ meN- $\}$ dan usia 5 tahun lebih banyak muncul pemerolehan afiksasi. (3) Pada tataran sintaksis, anak yang berusia 3 tahun hanya memperoleh ujaran dua kata, sedangkan anak yang berumur 4-5 tahun sudah memperoleh ujaran beberapa kata (4) Pada tataran semantik hampir semua ujaran anak mengandung makna denotatif, ada pula kalimat yang muncul dengan makna konotatif.

Anak-anak tersebut memperoleh bahasa secara bertahap sesuai dengan usianya dan sudah memiliki kemampuan untuk menghasilkan ujaran-ujaran yang sederhana sampai yang kompleks. Berdasarkan hasil penelitian ini, penulis menyarankan khusunya bagi orang tua yang memiliki anak yang berumur usia dini hendaknya sering melibatkan anak-anak dalam berkomunikasi, supaya kosa kata yang didapatkan lebih banyak dan bervariasi. Orang tua juga harus mengajarkan anak untuk lebih sering berinteraksi di lingkungan sekitarnya. Terutama untuk guru PAUD hendaknya memberikan contoh yang baik dalam segi bahasa kepada anak-anak usia dini, dikarenakan anak sering menirukan apa yang dilihat dan didengarnya. 
DAFTAR PUSTAKA

Basir, Udjang. 2010. Sosiolinguistik: Pengantar Kajian Tindak Berbahasa. Surabaya: Penerbit Bintang.

Chaer, Abdul. 2007. Linguistik Umum. Jakarta : Rineka Cipta

Chaer, Abdul. 2009. Psikolinguistik: Kajian Teoretik. Jakarta: Rineka Cipta
Chaer, Abdul. 2009. Sintaksis Bahasa Indonesia. Jakarta: Rineka Cipta

Chaer, Abdul dkk. 2004. Sosiolinguistik: Perkenalan Awal. Jakarta: PT Rineka Cipta.

Yulianto, Bambang. 2011. Pengantar Teori Belajar Bahasa. Surabaya: Unesa University Press 